\title{
Model Adaptive Blended Curriculum (ABC) sebagai Inovasi Kurikulum dalam Upaya Mendukung Pemerataan Pendidikan
}

\author{
Zahid Zufar At Thaariq*, Agus Wedi \\ Program Studi Teknologi Pendidikan, Universitas Negeri Malang, Malang, Indonesia \\ Pengiriman: 10/02/2020; Diterima: 17/10/2020; Publikasi: 20/11/2020 \\ DOI: 10.31629/kiprah.v8i2.2002
}

\begin{abstract}
Abstrak
Indonesia merupakan negara yang luas baik dari segi geografis maupun budaya. Dengan melihat luasnya wilayah tersebut, tentunya tiap-tiap sumber daya manusia pada tiap-tiap wilayah menjadi lebih beragam. Oleh karena itu, kajian ini bertujuan untuk mengajukan suatu inovasi model kurikulum yang dianggap tepat untuk diterapkan. Kurikulum yang baik di era sekarang tentunya tidak mengedepankan teacher centered learning, namun memprioritaskan student centered learning. Kurikulum secara adaptif sangat berpotensi untuk mewujudkan student centered learning. Maka dari itu, model semacam ini sangat tepat untuk diterapkan karena memenuhi unsur prinsip-prinsip dalam kurikulum, terutama prinsip relevansi dengan perkembangan zaman. Adaptive Blended Curriculum (ABC) merupakan suatu model inovasi kurikulum yang menekankan pada kurikulum secara blended (campuran) antara langsung dengan tidak langsung. Hasil dari kajian ini diharapkan dapat menjadi suatu referensi alternatif dalam penerapan kurikulum yang layak di Indonesia.
\end{abstract}

Kata kunci: kurikulum adaptif, kurikulum campuran (blended), model kurikulum

\begin{abstract}
Indonesia is a vast country both geographically and culturally. By looking at the extent of the area, of course each human resource in each region will be more diverse. So, this study aims to propose an innovative curriculum model that is considered appropriate to be applied. A good curriculum in the current era certainly does not prioritize teacher centered learning, but prioritizes student centered learning. Adaptive curriculum has the potential to realize student centered learning. Therefore, this kind of model is very appropriate to be applied because it fulfills the elements of the principles in the curriculum, especially the principle of relevance to the times. Adaptive Blended Curriculum (ABC) is a curriculum innovation model that emphasizes the curriculum blended direct and indirect. The results of this study are expected to become an alternative reference in implementing a proper curriculum in Indonesia.
\end{abstract}

Keywords: adaptive curriculum, blended curriculum, curriculum model

\section{PENDAHULUAN}

Indonesia adalah negara yang luas. Hal ini dapat dilihat dari secara geografis, Indonesia membentang dari $6^{0} \mathrm{LU}$ sampai $11^{\circ} \mathrm{LS}$ dan $92^{\circ}$ sampai $142^{\circ} \mathrm{BT}$, terdiri dari pulau-pulau besar dan kecil yang jumlahnya kurang lebih 17.504 pulau. Tiga perempat wilayahnya adalah laut $\left(5,9\right.$ juta $\left.\mathrm{km}^{2}\right)$, dengan panjang garis pantai
$95.161 \mathrm{~km}$, terpanjang kedua setelah Kanada (Lasabuda, 2013). Di samping letak geografisnya yang sangat luas, Indonesia juga terkenal sebagai negara yang kaya akan budaya yang tercipta melalui kekayaan suku di Indonesia. Sejauh ini masih terjadi perbedaan pemahaman dalam mengartikan konsep suku bangsa, sehingga berapakah tepatnya jumlah 
suku bangsa di Indonesia (Brata, 2016). Ada yang mengatakan bahwa di Indonesia terdapat sekitar 300 suku bangsa (Geertz, 1981), bahkan ada yang menyebutkan jauh lebih banyak dari jumlah tersebut. Melalatoa (1997) mencatat tidak kurang dari 520 suku bangsa di Indonesia dengan berbagai kebudayaannya.

Pendidikan merupakan suatu dasar tranformasi budaya sebagai jati diri bangsa. Hal ini akan membentuk pola berpikir tiap manusia. Pendidikan memiliki topik yang sangat luas. Hal ini dikarenakan pendidikan merupakan kunci dasar pembangunan manusia. Terdapat beberapa tantangan bagi pelaku pendidikan, khususnya guru dalam proses pendidikan. Pertama, guru perlu membuat keputusan tentang status materi yang mereka ajarkan: Apakah itu benar? Apakah penting apakah itu benar? Kedua, guru perlu mengevaluasi "pengetahuan" yang datang kepada mereka dari penelitian pendidikan. Ketiga, guru harus memutuskan apakah pengetahuan yang sejak lama disediakan untuk beberapa siswa harus atau dapat diakses oleh semua siswa (Noddings, 2018). Oleh karena itu untuk menjawab tantangan tersebut, perlu adanya alat yang membantu bernama kurikulum.

Kurikulum merupakan bagian terpenting dalam kelengkapan proses pendidikan. Kurikulum merupakan inti dari proses pendidikan (Meyer, Potter, \& Gary, 1997; Vitikka, Krokfors, \& Hurmerinta, 2012) karena itu di antara bidang-bidang pendidikan yaitu: manajemen pendidikan, kurikulum, dan layanan siswa, kurikulum merupakan bidang yang paling langsung berpengaruh terhadap hasil pendidikan. Pengembangan kurikulum tersebut minimal salah satu di antaranya terdapat desain kurikulum atau kurikulum tertulis (Sukmadinata, 2003). Desain kurikulum dapat bersifat menyeluruh, mencakup semua rancangan dan komponen kurikulum, tetapi bisa juga hanya berkenaan dengan salah satu bentuk desain atau rancangan saja (Nurdin, 2018). Desain kurikulum perlu mengacu pada tiga aspek yang di antaranya subject centered design, learner centered design, dan problem centered design. Subject centered design berpusat pada bahan ajar, media maupun sumber belajar lainnya; learner centered design yang mengutamakan peranan siswa; dan problem centered design yang berpusat pada masalah-masalah yang dihadapi oleh masyarakat (Sukmadinata, 2019).

Kurikulum yang baik adalah kurikulum yang mampu menjadi alat untuk pemerataan pendidikan. Hal ini sesuai dengan amanat Undang-Undang Sistem Pendidikan Nasional (Hakim, 2016). Pemerataan pendidikan dimaksudkan sebagai langkah dalam memaksimalkan potensi akademik secara merata sesuai dengan karakteristiknya, baik waktu maupun tempat. Untuk mewujudkan hal tersebut, diperlukan suatu bentuk reformasi pada dunia pendidikan di Indonesia mengingat masih terdapat berbagai bentuk permasalahan yang dihadapi pendidikan nasional meliputi: ketidakseimbangan daya tampung, pemerataan pendidikan, masalah mutu pendidikan, dan relevansi pendidikan (Wahyudi \& Lutfi, 2019).

Tantangan dari kurikulum adalah memutuskan yang baik strategi untuk memilih tingkat kesulitan awal yang tepat dan parameter tugas selama pembelajaran (Hermann et al., 2019). Dengan luasnya wilayah disertai ragamnya budaya Indonesia, kebutuhan pendidikan juga semakin beragam. Jadi, untuk menjawab hal tersebut, dibutuhkan kurikulum yang mampu mengakomodasi keragaman tersebut. Kurikulum tersebut bernama kurikulum adaptif.

Kurikulum adaptif adalah kurikulum yang mampu memenuhi kebutuhan pendidikan siswa yang beragam. Hal ini berawal dari pendapat dari Wescourt, Beard, \& Gould (1977), yang mengatakan

"One aspect of tutoring skill for technical subjects is individualized, adaptive sequencing of the problems given to students as learning exercises".

Kurikulum adaptif merupakan kurikulum nasional yang diadaptasi/diadopsi melalui penyesuaian unsur-unsur kebutuhan atau kondisi, kemampuan dan keterbatasan peserta didik (Laili, 2014). Menurut pendapat yang dikemukakan oleh Lee dkk., (2006), mereka mengatakan

"Curriculum adaptations refer to efforts to Curriculum Augmentation and Adaptation modify the way in which content is represented or presented or in which the student engages 
with and responds to the curriculum".

Sedangkan Alton dan Mackinnon dalam Mzizi (2014) mengatakan

"Curriculum adaptations involve making changes by eliminating or adapting parts of the curriculum as well as the teaching and leaning environtment, which enables learners to learn from the curriculum dessigned for their age group in an inclusive education setting".

Kurikulum adaptif adalah yang kurikulum yang didorong oleh data, berkisar pada penilaian dan umpan balik dalam siklus yang cepat untuk meningkatkan baik peserta didik maupun program pendidikan (Carney, Mejicano, Bumsted, \& Quirk, 2018). Data yang dapat diakses, valid, dan andal digunakan oleh peserta didik/pebelajar, guru/instruktur, dan kepemimpinan pendidikan untuk menguji asumsi, mengkalibrasi ulang, dan membuat keputusan untuk menerapkan tindakan yang tepat. Dalam penilaiannya terutama ketika difasilitasi oleh guru (Deiorio, Carney, Kahl, Bonura, \& Juve, 2016), mendorong proses metakognitif peserta didik yang menciptakan pemahaman yang lebih besar melalui penyesuaian diri dan situasinya (Sandars, 2009).

Kurikulum adaptif membuat perubahan dengan menghilangkan atau mengadaptasi bagian dari kurikulum seperti kegiatan belajar mengajar yang memungkinkan peserta didik belajar dari kurikulum yang didesain sesuai untuk kelompok usia mereka dalam setting pendidikan inklusif (Puspitarini, 2017). Proses penyusunan kurikulum adaptif, ditempuh dengan cara benchmarking curriculum. Secara umum diketahui bahwa benchmarking curriculum atau kurikulum rujukan adalah proses untuk mendukung peningkatan kurikulum melalui kombinasi antara kurikulum dalam negeri dengan kurikulum luar negeri, di mana negara luar yang menjadi acuan penilaian adalah negara maju (Isno, 2018). Modifikasi (penyelarasan) kurikulum adaptif diterapkan pada empat komponen utama kurikulum yaitu tujuan, isi, proses, dan evaluasi (Mukarromah, 2016).

Kurikulum secara adaptif dapat digunakan sebagai acuan dalam proses pembelajaran. Hal ini berdasarkan penelitian kualitatif dari Wulandari (2016), bahwa pelaksanaan dari kurikulum adaptif dapat ditarik kesimpulan tidak hanya menggunakan mata pelajaran maupun penilaian yang bersifat kompetensi bidang, namun juga mempertimbangkan asas kemanusiaan yang dimilikinya. Adapun terkait hasil belajar dengan menggunakan model adaptif tersebut, berdasarkan hasil penelitian kualitatif dari Taufan, Ardisal, Damri, \& Arise (2018) menunjukkan adanya keseimbangan hasil belajar yang diperoleh siswa dengan menggunakan model adaptif. Ini dikarenakan pada hakikatnya model adaptif mengutamakan sisi humanistik dalam prosesnya.

Salah satu upaya yang dapat dilakukan adalah dengan kesesuaian materi yang disampaikan. Kesesuaian tersebut tujuannya adalah mengakomodasi pengalaman belajar secara konstruktif dengan student centered learning. Maka dari itu, kesesuaian materi yang diajarkan merupakan komponen yang penting. Namun, permasalahan yang terjadi saat ini adalah kurangnya kesesuaian pembelajaran dengan karakteristik peserta didik. Akhirnya timbul masalah yang dimulai dari belajar yang tidak sesuai minatnya, tidak sesuai bakatnya, tidak sesuai kebutuhan, tidak sesuai kecakapan, dan ketidaksesuaian lainnya (Munir, 2017). Hal ini dikarenakan kurangnya pengalaman belajar yang mereka peroleh selama kegiatan pembelajaran berlangsung.

Salah satu upaya yang telah dikembangkan dalam memaksimalkan pengalaman belajar adalah melalui blended learning. Blended Learning adalah program $/ \mathrm{model} /$ strategi pembelajaran yang menggabungkan dengan sedemikian rupa antara strategi sinkron dan asinkron sebagai upaya untuk menciptakan pengalaman belajar seoptimal mungkin untuk mencapai hasil pembelajaran yang diharapkan (Stein \& Graham, 2014). Blended learning memiliki tujuan untuk mengoptimalkan kegiatan pembelajaran menjadi lebih baik dan memfasilitasi karakteristik serta kemandirian belajar (Al Aslamiyah, Setyosari, \& Praherdhiono, 2019). Penyampaian blended learning berfokus pada penyediaan catatan pembelajaran dan sumber daya tambahan untuk 
siswa masih merupakan kegiatan yang paling umum didukung (Havemann, Charles, Sherman, Rodgers, \& Barros, 2019). Ketika siswa secara aktif menyumbangkan ide dan mendiskusikannya bersama-sama, mereka saling menguntungkan (Alrushiedat \& Olfman, 2019). Blended learning memungkinkan siswa untuk mencapai kinerja pembelajaran yang lebih tinggi melalui strategi interaktif yang jelas yang melibatkan aktivitas pembelajaran tatap muka dan non tatap muka (Lu et al., 2018). Sehingga dengan adanya blended learning ini memungkinkan pebelajar untuk memiliki kebebasan dalam belajar, namun tetap mendapatkan bimbingan yang intens dari guru/pengajar itu sendiri.

Berdasarkan permasalahan yang telah dijabarkan, dibutuhkan suatu inovasi pengembangan kurikulum untuk menjawab tantangan-tantangan tersebut. Model Adaptive Blended Curriculum (ABC) adalah model kurikulum yang penerapannya menggunakan pendekatan synchronous dan asynchronous secara adaptif yang disesuaikan dengan situasi kondisi di daerah si belajar. Gagasan ini berdasarkan kombinasi teori antara adaptive learning, adaptive curriculum dan blended learning. Sehingga penerapannya dapat adaptif menyesuaikan lingkungan belajarnya dan mampu meningkatkan kompetensi yang ada pada dirinya (Kuswandi, Surahman, Thaariq, \& Muthmainnah, 2018; Surahman, Kuswandi, Wedi, \& Thaariq, 2019).

\section{METODE PENELITIAN}

Adapun metode yang digunakan dalam kajian ini adalah menggunakan telaah pustaka. Metode semacam ini dirasa penting karena tanpa ini peneliti tidak akan memperoleh pemahaman tentang topik terhangat, tentang apa yang telah dilakukan tentang itu, bagaimana itu telah diteliti, dan apa masalah utamanya. Di samping itu, metode telaah pustaka merupakan bagian dari pengembangan akademis (Hart, 2018). Alur dalam melakukan kajian ini adalah (1) mencari dan mengungkap fenomena/masalah yang terjadi; merumuskan gagasan; (3) melakukan komparasi-komparasi secara teoretis; dan (4) membua kesimpulan. Untuk menyajikan lebih banyak informasi, penulis banyak mencari berbagai sumber baik secara online melalui jurnal-jurnal yang tersedia maupun offline melalui berbagai buku-buku yang dimiliki penulis. Melalui sumber-sumber tersebut, penulis melakukan penarikan simpulan bahwa model $\mathrm{ABC}$ adalah jawaban dari fenomenafenomena pendidikan yang dikaji setelah dilakukan analisis data sumber secara induktif. Maksudnya yaitu suatu analisis berdasarkan data yang diperoleh dan selanjutnya dikembangkan menjadi suatu simpulan yang menjadi anggapan (hipotesis) (Sugiyono, 2019).

\section{PEMBAHASAN}

\section{Posisi Kurikulum dan Pembelajaran dalam Pendidikan}

Kurikulum memiliki kedudukan yang sentral dalam pendidikan, sehingga kurikulum dalam pendefinisiannya sering mendapatkan perdebatan secara internasional (Lynch, McCormack, \& Hennessy, 2017). Secara umum, kurikulum merupakan seperangkat rencana yang akan dilakukan dalam proses pelaksanaan pembelajaran. Rencana tersebut berkaitan dengan materi yang akan diajarkan, model yang akan dipakai, metode yang akan dipakai, sumber belajar maupun media pembelajaran yang akan dipakai.

Kurikulum dan pembelajaran merupakan hal yang tidak dapat dipisahkan walaupun keduanya memiliki kedudukan yang berbeda.. Kurikulum berfungsi sebagai landasan yang memberikan arah dan tujuan pendidikan, serta isi yang harus dipelajari (Syam, 2017). Sementara itu, pembelajaran adalah proses yang terjadi dalam interaksi belajar dan mengajar antara guru dan siswa. Dengan demikian, pendidikan tanpa kurikulum sebagai sebuah rencana, akan membuat pembelajaran atau pengajaran tidak berjalan dengan efektif dan efisien (Syam, 2017). Berdasarkan keterikatan fungsi tersebut, menjadikan adanya kurikulum dapat mempengaruhi proses pembelajaran yang dilaksanakan. 
Kurikulum Adaptif dan Paradigma Pendidikan Humanistik

Terdapat banyak paradigma pendidikan, salah satunya paradigma pendidikan humanistik. Dalam pandangan Abdurahman Mas'ud, humanisme dalam pendidikan adalah proses pendidikan yang lebih memerhatikan aspek potensi manusia sebagai makhluk sosial (berkemanusiaan) dan sebagai makhluk religius (berketuhanan), serta individu yang dapat mengembangkan potensipotensinya (Mas' ud, 2002). Teori humanistik adalah suatu teori yang bertujuan memanusiakan manusia. Artinya perilaku tiap orang ditentukan oleh orang itu sendiri dan memahami manusia terhadap lingkungan dan dirinya sendiri (Putri \& Ayu, 2012). Maka dalam hal ini, pendidikan humanistik menekankan pada nilai-nilai kemanusiaan di dalamnya.

Dalam pandangan humanistik, menurut Al-Fandi (2017) pendidikan harus diarahkan pada pengembangan dan kesadaran beberapa hal yaitu (1) manusia yang menyadari ada kekuatan yang Maha Agung yang mengatur hidup manusia; (2) manusia yang memahami dan melaksanakan hak dan kewajibannya sebagai manusia; (3) manusia yang memahami dan memanfaatkan potensi dirinya; (4) manusia yang menghargai dirinya sendiri sebagai manusia; (5) manusia yang menghargai manusia lain; (6) manusia yang bersedia menerima manusia lainnya dengan segala kelebihan dan kekurangannya; (7) manusia yang memiliki rasa percaya diri yang tinggi dan memiliki semangat untuk memperbaiki diri; (8) manusia yang tidak memaksakan kehendaknya atas manusia lain; (9) manusia yang menyadari bahwa setiap manusia memiliki karakteristik yang berbeda-beda; (10) manusia yang bertanggung jawab serta penuh kasih sayang terhadap manusia lain.

Jadi dalam pendidikan humanistik, setiap orang diposisikan sebagai subjek yang unik dengan kebutuhannya masing-masing yang berbeda kadar kebutuhannya. Pendidikan semacam ini memberikan perhatian kepada seluruh aspek diri dan karya manusia, baik pikiran, perasaan maupun tindakan (Toenlioe, 2018).

Kurikulum adaptif sangat mendukung pendidikan secara humanis. Hal ini dikarenakan komponen yang terdapat dalam kurikulum adaptif menyesuaikan situasi dan kondisi, sehingga secara baik siswa maupun guru dapat memiliki kenyamanannya dalam proses belajar mengajar. Di samping itu pada prinsipnya, pendidikan yang humanis dapat mengembangkan pribadi untuk menjadi individu yang terbuka, luwes dan adaptif (Daud, 2020), sehingga kurikulum adaptif memiliki keterkaitan dalam lingkungan pendidikan yang humanis.

\section{Kurikulum Adaptif dan Paradigma Belajar} Konstruktivisme

Manusia dalam hidup diberikan kemampuan untuk mengembangkan dan memaksimalkan potensi cipta, rasa dan karsanya dalam proses pemenuhan aneka macam kebutuhan hidup baik secara individu maupun kelompok (Arifin, 2013). Salah satu upaya yang dapat dilakukan memaksimalkan potensi diri manusia adalah melalui pembelajaran yang memberikan kebebasan dalam memaknai tentang pengetahuan yang dipelajarinya. Kebebasan semacam ini dinamakan konstruktivisme.

Konstruktivisme memandang bahwa pengetahuan adalah non objective bersifat temporer, selalu berubah, dan tidak menentu. Di samping itu dalam pandangan ini, pebelajar akan memperoleh pengetahuan melalui pemahaman yang tergantung pada pengalaman belajarnya dan perspektif yang dipakai dalam menginterpretasikan (Degeng, 1998). Secara sederhana, paradigma pembelajaran tersebut mengalami perubahan dari umum ke khusus, dari kompleks ke sederhana, dari menyeluruh ke parsial hingga dari berat ke ringan (Surahman, 2019). Pengembangan pembelajaran semacam ini menjadi terpusat kepada peserta didik (student centered learning) (Surahman, Sulthoni, et al., 2019). Pembelajaran semacam ini mampu meningkatkan motivasi belajar (Thaariq, Kuswandi, Diana, \& Shelinawati, 2019). 
Pada hakikatnya, ada dua macam konstruktivisme yang sudah dikenal sampai saat ini, yaitu konstruktivisme psikologis dan konstruktivisme sosiologis (Martini, 2017). Konstruktivisme psikologis, ide dasarnya dikemukakan oleh Jean Piaget bahwa belajarnya peserta didik, merupakan suatu proses pembentukan personal, individual, dan intelektual yang timbul dari aktivitasnya sendiri di dalam kehidupan sehari-hari. Konstruktivisme sosiologis pertama kali dikemukakan oleh Emile Durkheim yang selanjutnya dikembangkan oleh ahli-ahli sosiobudaya, misalnya Peter Berger dan lainlain, dan belakangan ini dikembangkan oleh ahli-ahli pendidikan sains, seperti Barry Barnes dan Bruno Latour (Martini, 2017).

Ide dasar dari konstruktivisme
sosiologis adalah bahwa dinamika pembentukan pengetahuan pada peserta didik merupakan hasil pengaruh lingkungan sosialnya melalui investigasi terhadap lingkungan sekitar. Berbeda dengan pendapat Piaget dan Vygotsky, paham ini mengabaikan mekanisme pengaruh aspek psikologi individu peserta didik yang oleh Piaget dan Vygotsky dipercayai sebagai hal yang sangat penting di dalam proses pembentukan pengetahuan. Menurut konstruktivisme sosiologis, pengetahuan merupakan bentuk konstruksi kognitif yang tidak berbeda jauh dengan literacy construction pada manusia sehingga tidak mempunyai suatu kebenaran mutlak. Pendapat tersebut mempunyai implikasi yang sangat besar terhadap dunia pendidikan, khususnya pendidikan sains saat ini (Matthews, 2019; O'loughlin, 1992).

Esensi dari kurikulum adaptif memiliki keterkaitan yang berhubungan dengan paradigma belajar konstruktivistik. Hal ini dikarenakan kedua teori ini sama-sama memperhatikan aspek-aspek yang berkenaan dengan perbedaan manusia dalam belajar, seperti gaya belajar, motivasi belajar, minat belajar dan sebagainya. Di samping itu, kurikulum adaptif pada dasarnya berusaha menyesuaikan situasi dan kondisi, maka demikian sama halnya dengan paradigma belajar konstruktivistik yang juga menyesuaikan situasi dan kebutuhan belajar dari pebelajar untuk membentuk pengalaman belajar yang bermakna bagi dirinya.

Model Adaptive Blended Curriculum (ABC)

Dalam dunia pendidikan, interaktivitas dalam pembelajaran semakin dibutuhkan. Pembelajaran klasikal yang menjadi ajang transfer ilmu dan nilai dari guru kepada siswa hari ini tidak lagi kaku dan menakutkan layaknya pembelajaran yang terjadi sepuluh tahunan lalu. Guru sudah semakin mahir dalam memanfaatkan media pembelajaran, begitu pula dengan siswa yang sudah bisa mengakses bahan yang akan diajarkan oleh guru sebelum pembelajaran dimulai, yakni dari dunia maya maupun media sosial (Arif \& Setiyowati, 2018). Maka dari itu, model Adaptive Blended Curriculum (ABC) dirasa tepat untuk diterapkan sebagai bagian dari kurikulum dalam sistem pendidikan nasional.

Model pengembangan kurikulum yang digunakan dalam pengembangan Model ABC ini adalah model Oliva. Oliva \& Gordon II (2012) menyatakan prinsip pengembangan kurikulum merujuk pada suatu keyakinan dan pendirian yang dijadikan patokan dalam proses pengembangan kurikulum, terutama dalam fase perencanaan kurikulum (curriculum planning). Empat sumber prinsip pengembangan kurikulum, yaitu: data empiris (empirical data), data experimen (experiment data), cerita atau legenda yang hidup di masyarakat (folklore of curriculum), dan akal sehat (common sense) (Laelasari, Rahmawati, \& Ekadharma, 2017). Tahapan-tahapan pengembangan kurikulum sebagaimana dijelaskan oleh Oliva (1992) adalah sebagai berikut: (1) Tahap perencanaan, langkah awal dalam pengembangan kurikulum ini diisi dengan tahapan berpikir, pengambilan keputusan dan pengambilan langkah tindakan. (2) Tahap penerapan, Tahapan ini merupakan pelaksanaan atau tindakan, yakni mengenai bagaimana kurikulum itu harus disampaikan kepada sasaran atau siswa. (3) Tahap evaluasi, langkah akhir dalam pengembangan kurikulum ini mengandung pelaksanaan berupa menilai dan melihat keberhasilan pengembangan 
kurikukum terhadap siswa. Atas hasil penilaian dan pengamatan itulah diputuskan perlu atau tidaknya melakukan revisi. Langkah model Oliva ini secara eksplisit memunculkan perlunya pengembang kurikulum memahami kajian filosofis sebagai landasan dalam pengembangan kurikulum (Wara, 2007).

Inovasi yang ditawarkan dalam pengembangan kurikulum ini adalah model Adaptive Blended Curriculum (ABC). Model $\mathrm{ABC}$ merupakan kurikulum yang menitikberatkan pada pembelajaran tidak langsung dengan langsung. Jadi, penekanannya pada pembelajaran mandiri yang terbimbing. Model ABC secara teoretis merupakan gabungan dari adaptive curriculum, adaptive learning dan blended learning. Pendekatan yang digunakan adalah TRINGO (Ngerti, Ngrasa, Nglakoni) dari Ki Hadjar Dewantara. Jadi pebelajar tidak hanya mengalami proses ngerti saja, namun terdapat proses merasakan dari apa yang ia mengerti dan melakukan setelah proses mengerti dan merasakan tersebut (Diana, Kuswandi, \& Ulfa, 2019; Kuswandi, 2005). Cara yang dianggap tepat untuk dengan manusia, memiliki karakteristik yang berbeda-beda, seperti short term memory, working memory dan long term memory yang berbeda-beda (Schunk, 2012). Maka dari itu, diperlukan penyediaan kurikulum yang secara substansial dibedakan, yang ditentukan, direncanakan, diartikulasikan, permanen, berkelanjutan, dan dapat dipertahankan sesuai dengan kebutuhan siswa (Salkind \& Rasmussen, 2008). Penerapan ini cocok untuk menjawab tantangan zaman.

Implementasi yang diharapkan adalah sebagai berikut (1) pada pembelajaran di kelas, penyesuaian karakteristik peserta didik melalui penerapan indoor dan outdoor learning; (2) pada guru, dilakukan pelatihan sertifikasi guru, khususnya terkait karakteristik siswa dan peran guru sebagai fasilitator pembelajaran di kelas; (3) pada tingkat sekolah, berfungsinya semua perangkat pendidikan di tiap sekolah. Contohnya seseorang lulusan Teknologi Pendidikan berperan sebagai analis pembelajaran maupun pengembang kurikulum sekolah; (4) kombinasi teori belajar antara konstruktivis, humanis dan behavioris untuk

\begin{tabular}{|c|c|c|}
\hline $\begin{array}{l}\text { Perencanaan } \\
\text { - Analisis Kebutuhan } \\
\text { Pebelajar } \\
\text { - Analisis Kebutuhan } \\
\text { - Pembelajar/Pengajar/Guru } \\
\text { - Analisis Kebutuhan } \\
\text { Sekolah } \\
\text { - Analisis Kebutuhan } \\
\text { Lembaga Kependidikan } \\
\text { - Analisis Kebutuhan } \\
\text { Masyarakat } \\
\text { - Analisis Kebutuhan } \\
\text { Disiplin Ilmu } \\
\text { - Studi Pustaka } \\
\text { - Merancang kurikulum } \\
\text { ABC }\end{array}$ & \begin{tabular}{l}
\multicolumn{1}{c}{ Penerapan } \\
- Menerapkan ABC sesuai \\
dengan perencanaan yang \\
telah disusun \\
- Seleksi model \\
pembelajaran sesuai \\
kebutuhan pembelajaran \\
- Seleksi sumber belajar \\
sesuai kebutuhan \\
pembelajaran \\
- Seleksi metode \\
pembelajaran sesuai \\
kebutuhan \\
- Seleksi pembelajaran yang \\
dilakukan secara blended \\
- Seleksi tujuan \\
pembelajaran sesuai \\
kebutuhan
\end{tabular} & $\begin{array}{l}\quad \text { Evaluasi } \\
\text { - } \text { Penilaian berbasis } \\
\text { kualitatif terhadap } \\
\text { pebelajar } \\
\text { - Penilaian keberhasilan } \\
\text { guru secara kualitatif } \\
\text { - Seleksi teknik evaluasi } \\
\text { pembelajaran } \\
\text { - Penilaian berdasarkan } \\
\text { Peer-Assessment dan Self- } \\
\text { Assessment } \text { - } \\
\text { - Tolak Ukur pembelajaran } \\
\text { berdasarkan pencapaian } \\
\text { yang diterima pebelajar } \\
\text { secara adaptif }\end{array}$ \\
\hline
\end{tabular}

Gambar 1 Gambaran Rancangan Pengembangan Kurikulum ABC menggunakan model Oliva

diterapkan adalah penerapan kurikulum secara adaptif. Adaptif maksudnya menyesuaikan karakteristik pebelajar baik dari segi psikologi maupun lingkungannya. Secara psikologi misalnya, setiap siswa sebagaimana halnya mencapai pembelajaran yang maju dengan memprioritaskan student-centered learning; (5) penyesuaian materi pelajaran dengan karakteristik siswa. Karakteristik siswa dinilai melalui tes gaya belajar dan bakat minat serta 
preferensi; (6) Pelajaran dasar yang wajib ada di setiap jenjang adalah Agama, Pancasila dan kewarganegaraan, Bahasa Indonesia, Bahasa Inggris, Muatan Lokal, Pendidikan Anti Korupsi; (7) pelajaran wajib tersebut bersifat pembelajaran secara dasar yang fundamental untuk kehidupan; (8) Untuk mata pelajaran lainnya disesuaikan dengan kebutuhan jenjang yang bersifat dasar dalam praktik kehidupan yang akan dihadapi oleh peserta didik (9) mengedepankan Ngerti, Ngrasa dan Nglakoni pada pengembangan potensi bakat minat siswa; (10) tolak ukur keberhasilan belajar terletak pada berkembangnya bakat minat siswa; (11) optimalisasi media dan sumber belajar secara adaptif; (12) penilaian dilakukan dengan mengedepankan akhlak dan potensi bakat minat secara kualitatif deskriptif; (13) pelibatan unsur guru dalam pengembangan kurikulum, dikarenakan guru merupakan pelaksana pembelajaran yang telah mengenal asam garam pembelajaran di kelas (Alsubaie, 2016); (14) peran guru sebagai pembelajar yang berfokus pada pengembangan potensi dan karakter; (15) tiap guru, perlu memiliki partner pengembang pembelajaran (lulusan Teknologi Pendidikan) yang membantu guru secara profesional dalam mengembangkan pembelajaran di kelas; (16) proses belajar mengajar yang menekankan pada tujuan, materi, metode, media dan evaluasi pembelajaran (Thaariq, Laili, \& Mulyawati, 2019); dan (17) pendayagunaan sumber belajar yang adaptif dengan karakteristiknya dengan mengedepankan pesan, orang, bahan, alat, teknik dan latar menggunakan preskripsi strategi penyampaian yang berorientasi pada sumber belajar, interaksi pebelajar dengan sumber belajar dan bentuk belajar mengajar (Wedi, 2017). Dengan menerapkan keseluruhan langkah tersebut secara tak langsung akan membuat suatu sekolah menjadi lebih inklusif.

Melalui konsep kurikulum tersebut, tentunya akan memudahkan siswa dalam belajar maupun guru dalam kegiatan belajar mengajar di kelas. Manfaat dari adanya Model ABC adalah (1) membantu untuk mengembangkan keterampilan, pengetahuan, dan pemahaman dalam konteks yang bermakna; (2) sebagai stimulus untuk melatih berpikir kritis dan kreatif; (3) mengembangkan kesadaran kompleksitas dunia nyata; (4) lebih memahami relevansi mata pelajaran yang diberikan; dan (5) memberikan pengalaman belajar secara efektif dan relatif santai sebagaimana pendapat yang dikemukakan Rosyid, Rofiqi, \& Yumnah (2019). Dengan berbagai manfaat tersebut sangat memungkinkan untuk terjadinya pemerataan pendidikan di Indonesia.

\section{Landasan Pengembangan Model Adaptive Blended Curriculum}

Tentunya, banyak hal yang harus dipertimbangkan dalam pengembangan kurikulum, salah satunya adalah landasan pengembangan kurikulum (Bahri, 2017). Terdapat empat landasan dari pengembangan model Adaptive Blended Curriculum, yaitu (1) landasan filosofis, (2) landasan psikologis, (3) landasan sosial budaya dan (4) landasan yuridis. Adapun penjelasannya adalah sebagai berikut

\section{Landasan Filosofis}

Landasan filosofis dari kurikulum berkenaan dengan landasan berpikir, teoritis, fakta dan data yang ada di lapangan. Maka, model ABC dikembangkan berdasarkan kebutuhan kurikulum pembelajaran yang mampu memberikan fokus belajar secara konstruktif pada peserta didik. Hal ini sesuai dengan pernyataan "Filosofi pendidikan menerangi ide-ide yang mendukung tindakan dan pemikiran dalam pendidikan. Pertanyaan filsuf adalah tentang sifat dan tujuan pendidikan: Apa yang membuat seseorang terdidik, bagaimana pengetahuan diklasifikasikan dan apa yang harus diajarkan?" (Bartlett \& Burton, 2016). Tanpa adanya filosofi pendidikan, sangat sulit bagi guru untuk memahami siswa selama proses pembelajaran (Kumral, 2016).

Adapun konsep dari model ABC didasari pada beragam permasalahan pendidikan, mulai dari kurikulum, pembelajaran, belajar, dll sebagaimana yang telah dijelaskan di pendahuluan. Model ABC 
dapat digunakan sebagai acuan pengembangan kurikulum nasional. Hal ini karena, secara filosofis, $\mathrm{ABC}$ merupakan singkatan dari Adaptive Blended Curriculum yang merupakan gabungan teoritis dari Adaptive Curriculum, Adaptive Learning dan Blended Learning. Adanya penerapan adaptive curriculum ataupun adaptive learning agar proses pelaksanaan pembelajaran dapat disesuaikan dengan situasi dan kondisi, baik ekonomi, sosial, geografis maupun wilayah. Sedangkan adanya blended learning dikarenakan untuk mencapai pengalaman belajar yang maksimal, maka pebelajar perlu belajar lebih melalui pengalaman di lapangan di samping pembelajaran secara formal. Itulah gambaran mengenai landasan filosofis dari model ABC.

Landasan Psikologis

Landasan ini mencakup mental atau psikis dari manusia (dalam hal ini adalah siswa dan guru). Maka, pengembangan model ABC memiliki 9 aspek landasan psikologis pengembangan kurikulum yang di antaranya mencakup (1) aspek ketakwaan, (2) aspek cipta, (3) aspek rasa, (4) aspek karsa, (5) aspek karya (kreatif), (6) aspek karya (ketrampilan), (7) aspek kesehatan, (8) aspek sosial dan (9) aspek individu (Sarie \& Kurniawan, 2014). Hal ini juga diadaptasi dengan psikologi perkembangan yang dikemukakan oleh Jean Piaget yang diambil dari beberapa tahapan yaitu (1) pra operasional, (2) operasi konkret, dan (3) operasi formal (Sukmadinata, 2019).

Pada aspek ketakwaan, model ABC sebagaimana terdapat kata "adaptive" maka menyesuaikan keberagaman agama khususnya yang ada di Indonesia. Pada aspek cipta, model ABC memiliki tujuan utama dalam peningkatan kemampuan daya saing pebelajar melalui daya cipta yang dimiliki masing-masing individu. Pada aspek rasa, karena dilakukan secara blended jadi pebelajar akan mendapatkan sentuhan rasa baik dari guru, orang tua maupun lingkungannya. Pada aspek karsa, pebelajar jadi lebih bertanggung jawab terhadap segala tugas yang diberikan. Pada aspek karya (kreatif), karena dilakukan secara adaptif dan blended, maka pebelajar semakin kreatif apabila diberikan penugasan. Pada aspek karya (ketrampilan), tentunya karena berorientasi pada blended learning, maka dapat meningkatkan ketrampilan secara mandiri. Pada aspek kesehatan, penerapan ini secara tidak langsung memengaruhi kesehatan, seperti contoh karena juga di luar kelas, maka tentu sekaligus pebelajar akan berolahraga, dan lain sebagainya. Pada aspek sosial, secara tidak langsung pebelajar akan berinteraksi secara terbuka dengan masyarakat maupun rekan sebayanya. Terakhir, pada aspek individu, tentu menjadi pengalaman tersendiri bagi pebelajar.

Landasan Sosial Budaya

Landasan ini berkaitan dengan lingkungan masyarakat. Maka, pengembangan model ABC ini bersifat adaptif dengan lingkungan sekitar. Hal ini juga didukung dengan pembelajaran blended yang memungkinkan siswa untuk mengeksplorasi pengalaman belajarnya secara lebih di luar kelas, namun tetap diberikan pendampingan oleh guru secara tatap muka. Model ABC sangat mendukung pemerataan pendidikan melalui peningkatan pengalaman belajar yang diterima oleh siswa.

\section{Landasan Yuridis}

Landasan ini berkaitan dengan hukum yang berlaku. Adapun model ABC digagas dengan berlandaskan UUD 1945 pasal 31 ayat 1 yang berbunyi "Tiap-tiap warga negara berhak mendapat pendidikan", ayat 2 yang berbunyi "setiap warga negara wajib mengikuti pendidikan dasar dan pemerintah wajib membiayainya" dan ayat 3 yang berbunyi "Pemerintah mengusahakan dan menyelenggarakan satu sistem pendidikan nasional dalam rangka mencerdaskan kehidupan bangsa yang diatur dengan undangundang" dan ayat 5 "Pemerintah memajukan ilmu pengetahuan dan teknologi dengan menjunjung tinggi nilai-nilai agama dan persatuan bangsa untuk kemajuan peradaban serta kesejahteraan umat manusia". Lalu, UUD 1945 Pasal 32 ayat 1 yang berbunyi "Negara memajukan kebudayaan nasional Indonesia di tengah peradaban dunia dengan menjamin kebebasan masyarakat dalam memelihara dan 
mengembangkan nilai-nilai budayanya" dan ayat 2 yang berbunyi "Negara menghormati dan memelihara Bahasa daerah sebagai kekayaan budaya nasional" (Majelis Permusyawaratan Rakyat, 2011).

Dalam Undang Undang Nomor 20 tahun 2003 tentang Sistem Pendidikan Nasional pasal 3 yang berbunyi "Pendidikan nasional berfungsi mengembangkan kemampuan dan membentuk watak serta peradaban bangsa yang bermartabat dalam rangka mencerdaskan kehidupan bangsa, bertujuan untuk berkembangnya potensi peserta didik agar menjadi manusia yang beriman dan bertakwa kepada Tuhan Yang Maha Esa, berakhlak mulia, sehat, berilmu, cakap, kreatif, mandiri, dan menjadi warga negara yang demokratis serta bertanggung jawab". Pasal 31 mengenai pendidikan jarak jauh pada ayat 3 yang berbunyi "Pendidikan jarak jauh diselenggarakan dalam berbagai bentuk, modus, dan cakupan yang didukung oleh sarana dan layanan belajar serta sistem penilaian yang menjamin mutu lulusan sesuai dengan standar nasional pendidikan" dan pasal 32 tentang pendidikan layanan khusus ayat 2 yang berbunyi "Pendidikan layanan khusus merupakan pendidikan bagi peserta didik di daerah terpencil atau terbelakang, masyarakat adat yang terpencil, dan/atau mengalami bencana alam, bencana sosial, dan tidak mampu dari segi ekonomi”

\section{KESIMPULAN}

Model Adaptive Blended Curriculum (ABC) merupakan suatu inovasi model kurikulum yang menekankan pada proses pengalaman belajar yang menyesuaikan karakteristik peserta didik. Karakteristik tersebut dilihat dari segi sosiologis, geologis, ekonomi dan budaya. Penyesuaian tersebut bertujuan agar peserta didik dapat belajar tanpa harus mengalami tekanan. Dalam konsep implementasinya, perlu adanya proses analisisanalisis sumber daya yang dapat mendukung proses pembelajaran, rancangan kurikulum yang menyesuaikan, kurikulum yang mendayagunakan sumber belajar yang ada, kurikulum yang di dalamnya terdapat rancangan pembelajaran secara blended hingga evaluasi yang humanis berorientasi kepada pebelajar. Maka dari itu, dukungan guru dan stakeholder pendidikan sangat dibutuhkan dalam penerapan ini, sehingga kajian model $\mathrm{ABC}$ ini dapat bermanfaat untuk masyarakat.

\section{UCAPAN TERIMA KASIH}

Artikel ini merupakan publikasi hasil penelitian dengan skema Penelitian Mahasiswa secara mandiri. Penulis berterima kasih kepada Dr. Agus Wedi, M.Pd selaku pembimbing dan penulis dari artikel yang dikaji.

\section{REFERENSI}

Al Aslamiyah, T., Setyosari, P., \& Praherdhiono, H. (2019). Blended Learning dan Kemandirian Belajar Mahasiswa Teknologi Pendidikan. Jurnal Kajian Teknologi Pendidikan, 2(2), 109-114.

Al-Fandi, H. (2017). Desain Pembelajaran yang Demokratis dan Humanis. Yogyakarta: Ar-Ruzz Media.

Alrushiedat, N., \& Olfman, L. (2019). Aiding participation and engagement in a blended learning environment. Journal of Information Systems Education, 24(2), 5.

Alsubaie, M. A. (2016). Curriculum Development: Teacher Involvement in Curriculum Development. Journal of Education and Practice, 7(9), 106107.

Arif, A. Z., \& Setiyowati, A. (2018). Piagam Debest: Integrasi Komitmen Tripusat Pendidikan Untuk Penguatan Pendidikan Karakter di SD Muhammadiyah 24 Surabaya. ELSE (Elementary School Education Journal): Jurnal Pendidikan Dan Pembelajaran Sekolah Dasar, 1(2b).

Arifin. (2013). Pedoman Praktis Penelitian Pendidikan, Pendekatan Kuantitatif dan Kualitatif (PTK). Bantul: Lilin Persada Press.

Bahri, S. (2017). Pengembangan Kurikulum Dasar Dan Tujuannya. Jurnal Ilmiah Islam Futura, 11(1), 15-34. 
Bartlett, S., \& Burton, D. (2016). Introduction to education studies. California: Sage.

Brata, I. B. (2016). Kearifan budaya lokal perekat identitas bangsa. Jurnal Bakti Saraswati (JBS), 5(1).

Carney, P. A., Mejicano, G. C., Bumsted, T., \& Quirk, M. (2018). Assessing learning in the adaptive curriculum. Medical Teacher, 40(8), 813-819.

Daud, R. M. (2020). Pendekatan Pengembangan Kurikulum Pendidikan di Aceh. PIONIR: JURNAL PENDIDIKAN, 9(1).

Degeng, I. N. S. (1998). Mencari Paradigma Baru Pemecahan Masalah Belajar dari Keteraturan Menuju Kesemrawutan. Makalah Disajikan Dalam Pidato Pengukuhan Guru Besar IKIP Malang.

Deiorio, N. M., Carney, P. A., Kahl, L. E., Bonura, E. M., \& Juve, A. M. (2016). Coaching: A new model for academic and career achievement. Medical Education Online, 21(1), 33480.

Diana, R. C., Kuswandi, D., \& Ulfa, S. (2019). Konsep Pembelajaran TRINGO pada Mata Kuliah Model Pengembangan Kurikulum. Jurnal Kajian Teknologi Pendidikan, 2(2), 90-95.

Geertz, H. (1981). Aneka Budaya dan Komunitas di Indonesia (A. R. Zainuddin, Trans.). Jakarta: Yayasan Ilmu-Ilmu Sosial \& FIS-UI.

Hakim, L. (2016). Pemerataan Akses Pendidikan Bagi Rakyat Sesuai Dengan Amanat Undang-Undang Nomor 20 Tahun 2003 Tentang Sistem Pendidikan Nasional. EduTech: Jurnal Ilmu Pendidikan Dan Ilmu Sosial, 2(1).

Hart, C. (2018). Doing a literature review: Releasing the research imagination. London: Sage.

Havemann, L., Charles, E., Sherman, S., Rodgers, S., \& Barros, J. (2019). A multitude of modes: Considering 'blended learning'in context.

Hermann, L., Argus, M., Eitel, A., Amiranashvili, A., Burgard, W., \& Brox, T. (2019). Adaptive Curriculum
Generation from Demonstrations for Sim-to-Real Visuomotor Control. ArXiv Preprint ArXiv:1910.07972.

Isno, I. (2018). Model Adopsi Daptasi Kurikulum 2013 dan Cambridge University bagi Madrasah. Progressa: Journal of Islamic Religious Instruction, 2(2), 17-26.

Kumral, O. (2016). A Trial for Curriculum Development: The Effect of Educational Philosophy Curriculum on the Attitudes towards Course and Educational Views. Journal of Education and Training Studies, 4(3), 174-188.

Kuswandi, D. (2005). Pengejawantahan Konsep-Konsep Pendidikan Ki Hadjar Dewantara di Lingkungan Ibu Pawiyatan Tamansiswa Yogyakarta (Disertasi). Universitas Negeri Malang, Malang.

Kuswandi, D., Surahman, E., Thaariq, Z. Z. A., \& Muthmainnah, M. (2018). K-Means Clustering of Student Perceptions on Project-Based Learning Model Application. 2018 4th International Conference on Education and Technology (ICET), 9-12. IEEE.

Laelasari, E., Rahmawati, A., \& Ekadharma, A. (2017). Model Kurikulum Pendidikan Kesetaraan Program Paket C Mahir dalam Jaringan. Jakarta: Kementerian Pendidikan dan Kebudayaan.

Laili, A. N. (2014). Implementasi Kurikulum Adaptif dalam Pembelajaran Matematika Di Sma Khadijah Surabaya (Skripsi). UIN Sunan Ampel Surabaya.

Lasabuda, R. (2013). Pembangunan wilayah pesisir dan lautan dalam perspektif negara kepulauan Republik Indonesia. Jurnal Ilmiah Platax, 1(2), 92-101.

Lee, S.-H., Amos, B. A., Gragoudas, S., Lee, Y., Shogren, K. A., Theoharis, R., \& Wehmeyer, M. L. (2006). Curriculum augmentation and adaptation strategies to promote access to the general curriculum for students with 
intellectual and developmental disabilities. Education and Training in Developmental Disabilities, 199-212.

Lu, O. H., Huang, A. Y., Huang, J. C., Lin, A. J., Ogata, H., \& Yang, S. J. (2018). Applying learning analytics for the early prediction of Students' academic performance in blended learning. Journal of Educational Technology \& Society, 21(2), 220-232.

Lynch, R., McCormack, O., \& Hennessy, J. (2017). Exploring the position of curriculum studies across the continuum of teacher education in Ireland. Irish Educational Studies, 36(4), 439-456.

Majelis Permusyawaratan Rakyat. UndangUndang Dasar Negara Republik Indonesia tahun 1945. , (2011).

Martini, S. (2017). Landasan Filsafat Konstruktivisme dalam Pembelajaran Sains. Jurnal Mangifera Edu, 1(2), 3545.

Mas' ud, A. (2002). Menggagas format pendidikan nondikotomik:(humanisme religius sebagai paradigma pendidikan Islam). Yogyakarta: Gama Media.

Matthews, M. R. (2019). 7 The Contribution of Philosophy to Science Teacher Education. The Importance of Philosophy in Teacher Education: Mapping the Decline and Its Consequences, 121.

Melalatoa, M. J. (1997). Sistem Budaya Indonesia. Diterbitkan atas kerja sama Fakultas Ilmu Sosial dan Ilmu Politik, Universitas Indonesia dengan Penerbit PT. Pamator.

Meyer, G. S., Potter, A., \& Gary, N. (1997). A national survey to define a new core curriculum to prepare physicians for managed care practice. Academic Medicine: Journal of the Association of American Medical Colleges, 72(8), 669-676.

Mukarromah, I. (2016). Pelaksanaan Kurikulum Adaptif di Sekolah Penyelanggara Pendidikan Inklusi di
Sekolah Dasar Negeri Giwangan, Yogyakarta.

WIDIA

ORTODIDAKTIKA, 5(9), 908-917.

Munir, M. (2017). Pengaruh Penggunaan Metode Role Playing Terhadap Minat Belajar Siswa Kelas X Pada Materi Virus Di SMA Azharyah Palembang. Florea, 4(1).

Mzizi, N. A. (2014). Curriculum Adaptations fo Learners with Learning impairments in the Foundation Phase in Thabo Mofutsanyana Education District, Free State Province. Retrieved November 8, 2019, from http://ir.cut.ac.za/bitstream/handle/114 62/250/Mzizi,\%20Nompumelelo\% 20Alzinah.pdf?sequence $=1$

Noddings, N. (2018). Philosophy of education. Cumnor Hill: Routledge.

Nurdin, S. (2018). Pengembangan kurikulum dan rencana pembelajaran semester (RPS) berbasis KKNI di perguruan tinggi. Al-Fikrah: Jurnal Manajemen Pendidikan, 5(1), 21-30.

Oliva, P. F. (1992). Developing the curriculum. New York: Harper Collins Publishers.

Oliva, P. F., \& Gordon II, W. R. (2012). Developing the curriculum. London: Pearson Higher Ed.

O'loughlin, M. (1992). Rethinking science education: Beyond Piagetian constructivism toward a sociocultural model of teaching and learning. Journal of Research in Science Teaching, 29(8), 791-820.

Puspitarini, D. O. (2017). Kompetensi Guru dalam Implementasi Kurikulum Adaptif di Sekolah Dasar Inklusif (Skripsi). Universitas Negeri Semarang.

Putri, E., \& Ayu, I. (2012). Konsep Pendidikan Humanistik Ki Hajar Dewantara dalam Pandangan Islam. IAIN Walisongo.

Rosyid, Moh. Z., Rofiqi, \& Yumnah, S. (2019). Outdoor Learning: Belajar di Luar Kelas. Batu: Literasi Nusantara.

Salkind, N. J., \& Rasmussen, K. (Eds.). (2008). 
Encyclopedia of educational psychology. Thousand Oaks, Calif: Sage Publications.

Sandars, J. (2009). The use of reflection in medical education: AMEE Guide No. 44. Medical Teacher, 31(8), 685-695.

Sarie, K. W., \& Kurniawan, E. T. (2014). SILABUS, RPP dan Kurikulum dan Asas-Asas Kurikulum Nasional: Teori dan Pengembangan Kurikulum [Makalah]. Surabaya: Program Pascasarjana UNESA. Retrieved from Program Pascasarjana UNESA website:

http://www.academia.edu/download/3 5698542/RPP_SILABUS_DAN_AS AS_KURIKULUM.docx

Schunk, D. H. (2012). Learning theories: An educational perspective (6th ed). Boston: Pearson.

Stein, J., \& Graham, C. R. (2014). Essentials for blended learning: A standardsbased guide. New York: Routledge.

Sugiyono. (2019). Metode Penelitian Pendidikan (Kuantitatif, Kualitatif, Kombinasi, $R \& D$ dan Penelitian Pendidikan). Bandung: Alfabeta.

Sukmadinata, N. S. (2003). Dasar-Dasar Pengembangan Kurikulum perguruan Tinggi. Makalah Dalam Lokakarya Pengembangan Kurikulum Berbasis Kompetensi IAIN Sunan Gunung Jati Bandung.

Sukmadinata, N. S. (2019). Pengembangan Kurikulum: Teori dan Praktik. Bandung: Remaja Rosdakarya.

Surahman, E. (2019). Microlearning, Epistemologi Belajar di Era Digital. In Teori dan Implementasi Teknologi Pendidikan: Era Belajar Abad 21 dan Revolusi Industri 4.0. Malang: Seribu Bintang.

Surahman, E., Kuswandi, D., Wedi, A., \& Thaariq, Z. Z. A. (2019). Students' Perception of Project-Based Learning Model in Blended Learning Mode Using Sipejar. International Conference on Education Technology
(ICoET 2019). Atlantis Press. Surahman, E., Sulthoni, Toelioe, A. J. E., Thaariq, Z. Z. A., Qolbi, M. S., \& Nindigraha, N. (2019). Pengembangan Buku Ajar Hypercontent Terintegrasi Open Educational Resources (OER) untuk Meningkatkan Mutu Perkuliahan Program Pendidikan dan Pelatihan [Laporan Penelitian PNBP FIP]. Malang: Universitas Negeri Malang.

Syam, A. R. (2017). Posisi Manajemen Kurikulum Dan Pembelajaran Dalam Pendidikan. Muaddib: Studi Kependidikan Dan Keislaman, 7(01), 33-46.

Taufan, J., Ardisal, A., Damri, D., \& Arise, A. (2018). Pelaksanaan Pembelajaran Pendidikan Jasmani Adaptif bagi Anak dengan Hambatan Fisik dan Motorik. Jurnal Pendidikan Kebutuhan Khusus, 2(2), 19-24.

Thaariq, Z. Z. A., Kuswandi, D., Diana, R. C., \& Shelinawati, U. (2019). Factors that Influence Outstanding Student (Mawapres) in Learning Motivation. JPP (Jurnal Pendidikan Dan Pembelajaran), 26(2), 60-64.

Thaariq, Z. Z. A., Laili, N., \& Mulyawati, N. W. (2019). Pengembangan Adaptive Training Book for Disability Sebagai Katalisator Media Pelatihan Bagi Penyandang Disabilitas (Studi Perbandingan di Amerika, Finlandia dan Indonesia). LORONG: Media Pengkajian Sosial Budaya, 8(1).

Toenlioe, A. J. E. (2018). Ilmu dan Filsafat Pendidikan: Kajian Model Dikotomis Sinergis. Malang: Elang Mas.

Undang Undang Nomor 20 tahun 2003 tentang Sistem Pendidikan Nasional.

Vitikka, E., Krokfors, L., \& Hurmerinta, E. (2012). The Finnish national core curriculum. In Miracle of education (pp. 83-96). Springer.

Wahyudi, M. A., \& Lutfi, A. (2019). Analisis Reformasi Pendidikan dalam Mewujudkan Pemerataan Kualitas Pendidikan di Indonesia. Jurnal 
Z. Z. A. Thaariq, A. Wedi/ Jurnal Kiprah 8 (2) (2020) 91-104

Administrasi Publik (Public

Administration Journal), 9(2), 191201.

Wara, E. (2007). Filosofi Sebagai Landasan Pengembangan Kurikulum. Jurnal Manajemen Pendidikan UNY.

Wedi, A. (2017). Pendayagunaan Sumber Belajar dalam Implementasi Strategi Penyampaian Pembelajaran Tematik. Edcomtech Jurnal Kajian Teknologi Pendidikan, 1(1), 83-92.

Wescourt, K. T., Beard, M., \& Gould, L.
(1977). Knowledge-based adaptive curriculum sequencing for CAI: Application of a network representation. Proceedings of the 1977 Annual Conference, 234-240.

Wulandari, W. S. (2016). Pengelolaan Kurikulum Adaptif Mata Pelajaran Matematika Pada Program Sekolah Cluster Di SMKN 2 Purwodadi. Universitas Muhammadiyah Surakarta. 